International Journal of Modern Anthropology

Int. J. Mod. Anthrop. 2019. Vol. 2, Issue 12, pp: $189-212$

DOI: http://dx.doi.org/10.4314/ijma.v2i12.9

Available online at: www.ata.org.tn \& https://www.ajol.info/index.php/ijma

Research Report

\title{
“Latín" rock scripts in Canary Islands are ancient Iberian inscriptions (Iberian-Guanche) A story of forgotten genetics, scripts, pyramids and other prehistoric artifacts
}

\author{
Antonio Arnaiz-Villena*1, Adrian Lopez-Nares ${ }^{1}$, Ignacio Juárez ${ }^{1}$, Valentín Ruiz- \\ del-Valle ${ }^{1}$, Álvaro Callado ${ }^{1}$, Alejandro H-Sevilla ${ }^{1}$, Eduardo Gomez-Casado ${ }^{2}$ \\ Department of Immunology, University Complutense, School of Medicine, Madrid, Spain. \\ ${ }^{2}$ Department of Biotechnology, INIA, Madrid \\ * Corresponding autor: Antonio Arnaiz-Villena. Departamento de Inmunología, Facultad de Medicina, Universidad \\ Complutense, Pabellón 5, planta 4. Avda. Complutense s/n, 28040 Madrid, Spain. \\ E.mail: arnaizantonio@gmail.com. Website: http://chopo.pntic.mec.es/biolmol; http://basques-berians.blogspot.com
}

(Received 15 October 2019; Accepted 10 November 2019; Published 25 November 2019)

Abstract - "Latin" rock scripts were discovered 30 years ago in Lanzarote and Fuerteventura Islands (Canary Islands). However, they are an incised linear writing which lacks Q, H, P and T frequent Latin letters and translation into Latin has not been possible. A transcription and a translation hypothesis was proposed long ago because scripts were almost identical to those of the Iberian semi-syllabary which was used in Iberia and France during first millennium BC; "Latin" scripts were named "IberianGuanche" and were mostly religious and funerary. This type of lineal incise writing is present in all seven Canary Islands and they may have been unnoticed because all other islands except Lanzarote and Fuerteventura are humid and covered by vegetation. This type of linear writings are, like Iberian, similar to Runes (Atlantic and Central Europe),Old Italian scripts (Raetian, Venetic, Lepontic, Etruscan) and Sitovo and Gradeshnistsa scripts (Bulgaria, $5^{\text {th }}$ millennium BC). Language behind Iberian-Guanche scripts might be related to both Berber and Old Basque languages. People who wrote "Iberian-Guanche" inscriptions seem to be Canary Island inhabitants and not visitors. Genes (people) of present and past Canary Islanders are difficult only to assign to North Africa because gene flow between North Africa and Iberia existed in prehistoric times and it is difficult to distinguish Iberian and North African with Canarian gene profiles. Genetics by itself is not sufficient for relating people or specific for geography, this is firmly demonstrated for mitochondrial genes. Linguistics, Culture, and Archaeology are necessary to interpret population genetics data. Extant pyramids in North Africa, Western Sahara and possibly Tenerife, existence of prehistoric artifacts and rock calendars ("Quesera"/Cheeseborad lunisolar calendar at Lanzarote and others at Gran Canaria Island) and presence of Cart-Ruts on Lanzarote volcano tops, may indicate an older date for Canarian prehistory than that of Punic/Roman presence. Finally Canarian prehistoric findings have been long neglected and forgotten but a common IberianGuanche rock writing culture existed in Canary Islands. 
Keywords: Latin, Scripts, Canary Islands, Iberian, Guanche, Lybic, Lanzarote, Fuerteventura, Quesera, Cheeseboard, Pyramids, Berber, Africa, Punic, Roman, Western Sahara, Tunisia, Algeria, Canarian, Semi-Sillabary, Calendar, Raetian, Lepontic, Venetian, Etruscan, Basque, Cart-ruts, Sitovo, Gradeshnitsa, UskoMediterranean.

\section{Introduction}

Canary Islands (Spain) are placed in front of Moroccan Coast (Fig. 1). Their peopling is hotly debated and still unclear. Several hypotheses have been considered. North Africans, Mediterraneans, Atlantic Europeans seem all to have contributed to ancient Canarians or "Guanches" peopling (Arnaiz-Villena et al. 2015). North African and Iberian genes have been exchanged since prehistoric times as it is shown by using chromosome autosomical HLA genes (Arnaiz-Villena et al. 1999; 2002); this Iberian / North African gene flow has been also established by three other independent groups (Currat et al. 2010; Botigue et al. 2013; Gonzalez-fortes et al. 2019). Genetic differences between western Mediterraneans and North West Africans are scanty (Arnaiz-Villena et al. 2015, 2017; Hajjej et al. 2018) because prehistoric Atlantic Europe, North African and Canary Islands belong to a related cultural and genetic group (Arnaiz-Villena et al. 2017). Also, Canarian prehistory should in part be interpreted in the context of Megalithic Atlantic culture (Arnaiz-Villena et al. 2015; 2017; 2019a; Medina \& Arnaiz-Villena 2018a; 2018b). In addition, a big rock carved lunisolar calendar has been found in Lanzarote, (Canary Islands): "La Quesera"/Cheeseboard of Zonzamas (Marcial Medina \& Arnaiz-Villena 2018a; 2018b; Arnaiz-Villena et al. 2018).

Prehistoric Atlantic petroglyphs, mummifications, pyramids and possible megalithic buildings have been found (Medina and Arnaiz-Villena, 2018a; 2018b; Arnaiz-Villena et al. 2018; 2019a), particularly this lunisolar calendar "Cheeseboard" of Zonzamas in Lanzarote Island and also Cart-ruts rock carved channel structures on the top of volcanoes. Also, other most likely pre-Punic and pre-Roman prehistoric rock calendars have been found in Gran Canaria Island (Barrios Garcia 2004; Barrios Garcia 
et al. 2018) However, archaeological dating based on absolute objective methods are greatly lacking in Canary Islands archaeological patrimony with exceptions (Atoche Peña \& Ramirez Rodriguez 2009). In addition, pyramidal structures have been described in Canary Islands and not only in Tenerife, but also in Gran Canaria and La Palma (Ulbricht 2016) and also very similar ones in Western Sahara in continental, only about $95 \mathrm{Km}$ (59.03 miles) far from Fuerteventura Canary Island (Clarke \& Brooks 2018).

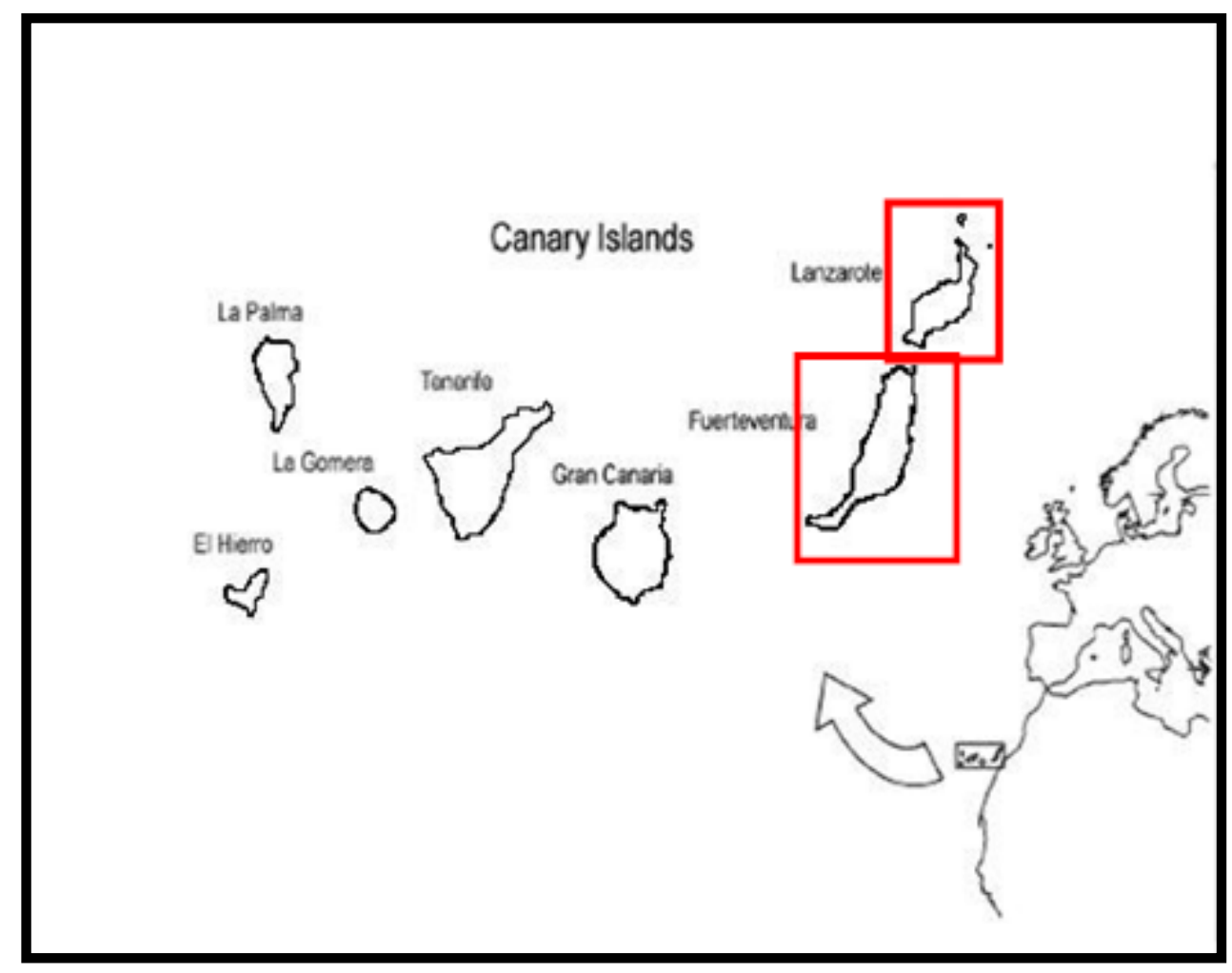

Fig. 1 Map of Canary Islands with their names and the Atlantic coast lines of Europe and North West Africa.

Lanzarote Island is $125 \mathrm{~km}$ (78 miles) apart off African Coast. Fuerteventura Island is at $97 \mathrm{~km}(60.27$ miles) of Africa coast.

In summary, it seems that Canary Islands have Cart-Ruts (Bronze Age in Malta) (Arnaiz-Villena et al. 2019a), pyramids which were widespread throughout North Africa (Fig. 2) Atlantic petroglyphs and rock carved monuments that are shown to be ancient astronomical observatories (Barrios Garcia 2004; Barrios-Garcia et al. 2018; Marcial Medina \& Arnaiz-Villena, 2018a; 2018b; Arnaiz-Villena et al. 2018; 2019a). 
This prehistoric canarian patrimony is more ancient than putative Phoenicians or Roman presence. In addition, genetics cannot distinguish whether many Canarian First Inhabitants were Iberians, North Africans; both of them and / or others by using autosomic genes because the heavy prehistoric genes flow between Iberia and North Africa (Arnaiz-Villena et al. 1999; 2002; 2015) in concordance with other authors (Currat et al. 2010; Botigue et al. 2013; Gonzalez-Fortes et al. 2019).

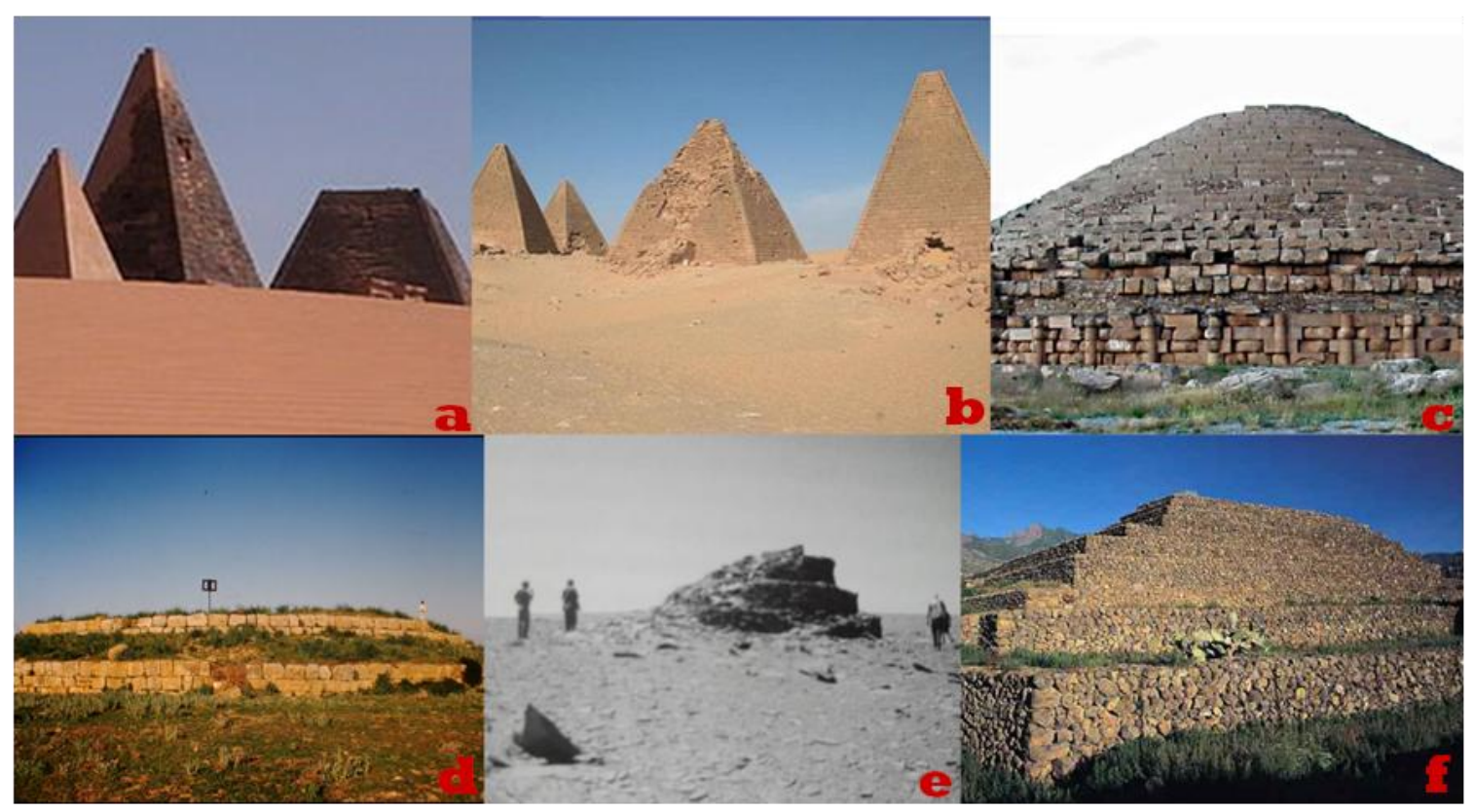

Fig. 2

a) Nubian pyramids. https://cosmolearning.org/images/nubian-pyramids-1051/

b) Libya pyramids, A wbari Town. https://www.pinterest.com/pin/333829391108380629/

c) Algeria pyramid, Frenda Region. https://www.aboutalgeria.com/2018/05/theamazighs-pyramids-of-jeddars-tombs.html

d) Morocco Pyramid (El Gour near Meknes) https://en.wikipedia.org/wiki/El_Gour,_Morocco)

e) Western Sahara pyramid (Clarke \& Brooks, 2019).

f) Guimar (Tenerife, Canary Islands) pyramid. https://www.tenerife-information-centre.com/pyramids-at-guimar.html

Two types of prehistoric inscriptions have been found in rocks throughout Canary Islands: a) Lybic-Berber (Springer-Bunk 2001) and b) the so called "Latin" inscriptions (Pichler 1995). Pichler published nearly 300 inscriptions from Fuerteventura. They were discovered in Lanzarote (Figs 3,4) but today there are many 
more collected there (AAV personal observation, Hernandez-Bautista \& Perera 1983; Ulbricht 1990; Pichler 1995; 2003). In addition, Nowak (1994) also reported this type of "Latin" inscriptions in the westernmost El Hierro Island. These presumed Latin inscriptions have not been translated by using Latin. In addition, C, Q, H, P and T typical Latin usual letters cannot be found. In year 2001, Arnaiz-Villena \& AlonsoGarcia, transcribed scripts which were identical to ancient Iberian language scripts (1998; 2001). Also, a hypothetical translation was put forward by using Basque language equivalence which is most likely a remaining ancient Iberian language inscription. Most "Latin" or "Iberian-Guanche" scripts published by Pichler were referring to religious and funerary topics (Arnaiz-Villena \& Alonso-Garcia 2001) (see Fig. 5) and

(https://commons.wikimedia.org/w/index.php?title=File:Iberian-Guanche_inscriptions. pdf\&page $=1$ ). These inscriptions are written in old Iberian semi-syllabary which has been used until $2^{\text {nd }}$ Century AD (Arribas 1976). It was found in rocks and other solid supports in southern France and Iberia during the $1^{\text {st }}$ millennium BC.

In the present paper, we aim to show that so called "Latin" inscriptions are written in Old Iberian semi-syllabary by using: a) direct transcription, b) a hypothesis of translation based on phonology and semantics and c) interpreting findings in a genetic and anthropological / archaeological context.

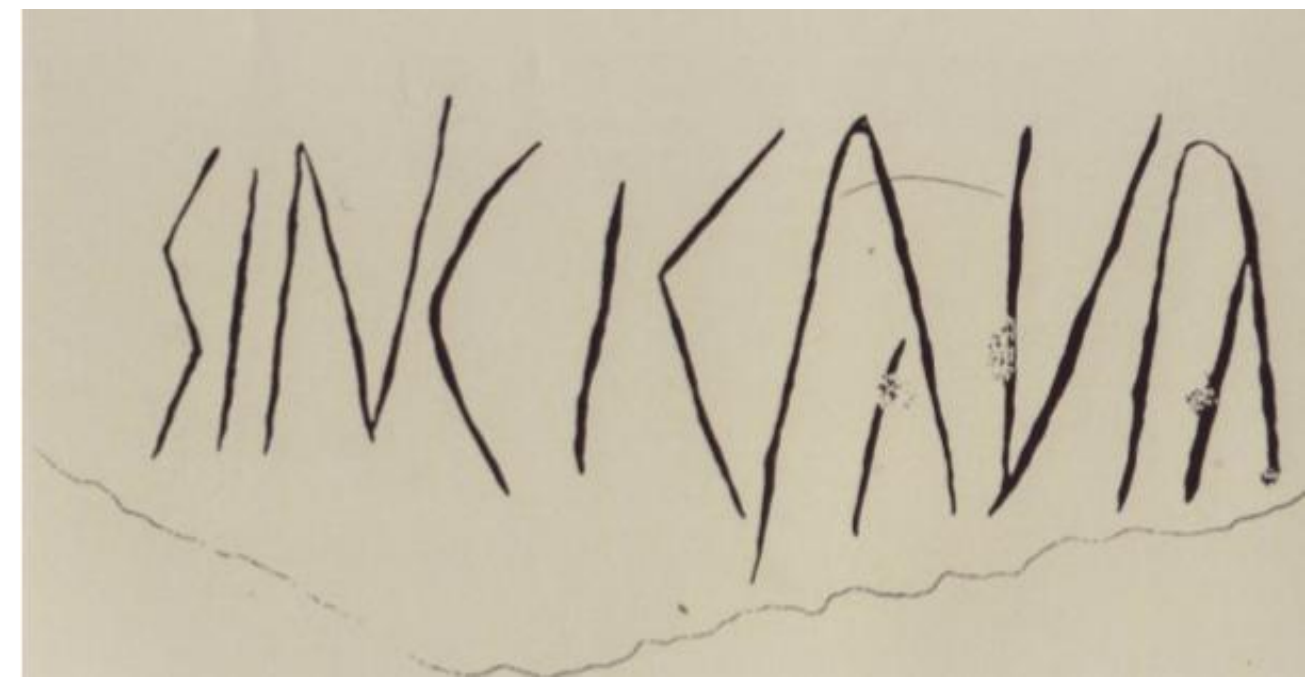

Fig. 3 A trace of "Latin" rock script found at Zonzamas, Lanzarote, close to Arrecife Town. 


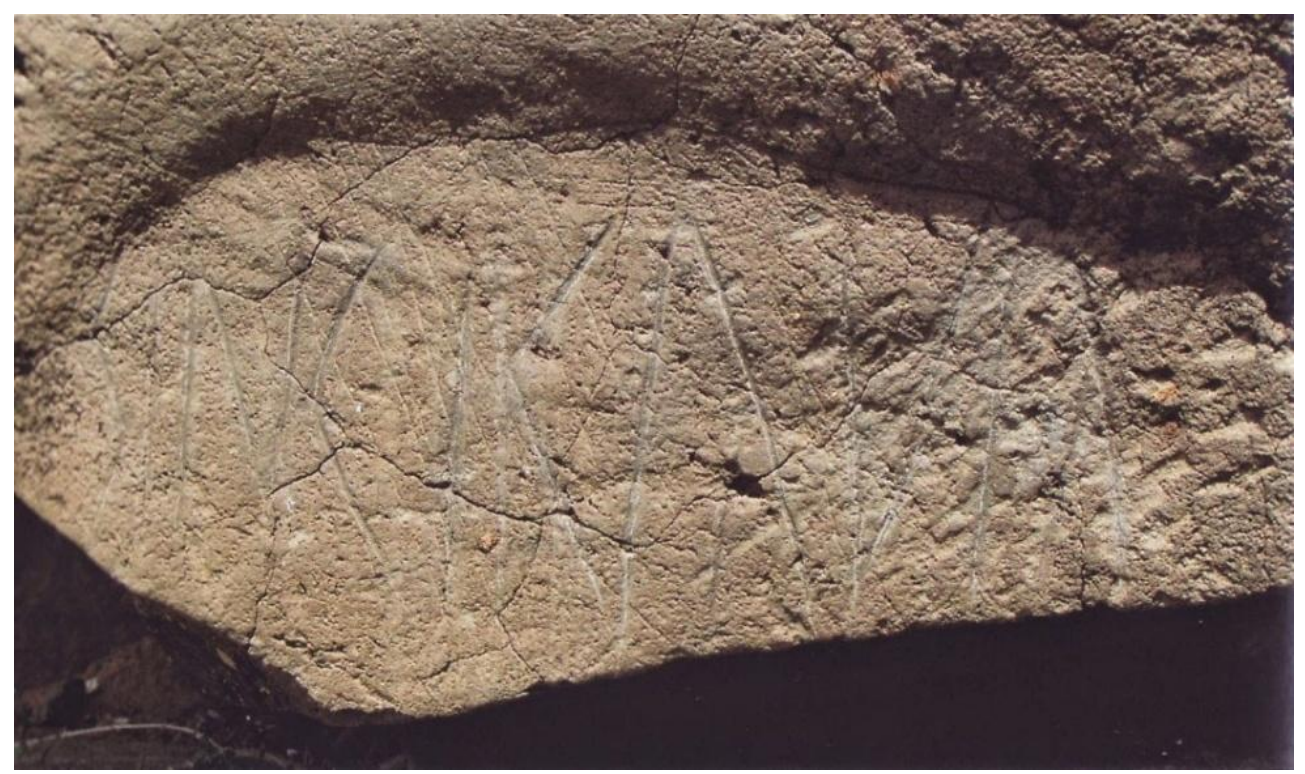

Fig. 4 Original rock script at Zonzamas. Note that surface has been polished.

\section{Material and Methods}

Methodology used for proposing a translation hypothesis for "Latin" or Iberian-Guanche Inscriptions (Arnaiz-Villena 2000)

We have followed a methodology which is similar to that proposed by Greenberg and Ruhlen (Ruhlen 1994).

Our premises for approaching these Usko-Mediterranean languages are:

1) Languages may correctly be classified and decipherment approached with 10-20 "diagnostic" cognates (i.e. the personal pronouns and other frequently used cognates like plant names, family generics and tools and common life terms existing in Neolithic and pre-Neolithic societies). In general, we use phonology and semantics similarities.

2) Most of the written ancient Mediterranean languages studied previously by us (i.e. Iberian-Tartesian, Etruscan, Linear A) refer to an apparently common religion (Poulianos 1969; Arnaiz-Villena \& Alonso-García 1998, 2001). This decipherment has been possible to the Basque-Spanish translation of words found in the above mentioned extinct languages and showing a Basque correspondence. The topics found in this 
religion are: the Mother (Ama= mother, in Basque (B.)), the way of the Zen (dead, in B.) towards another life, going through The Door or Atan (B.). The flames (Kar, B.), which make the dead to be afraid, etc.

3) Most of these deciphered "Usko-Mediterranean" languages refer to the following matters:

A. Religion and after death (90\%).

B. Accountancy related to food-storage and other topics.

This skewed thematic writing may be due to that writings have been better preserved in sanctuaries and/or palaces, and not in normal living people housing (the latter being constructed with more perishable materials). Also, Neolithic and preNeolithic societies may have used written words as a magic or totemic sense related to permanent keeping of possessions and also to securing a proper and pleasant after death life; casts of clerks (related or not to religion) could have further driven this tendency in order to keep up with privileges. In addition, it is obvious that primitive societies felt less secure that nowadays more complex ones; this could have led people to find religion and food register to be essential.

4) There are groups of words that are found together in the different languages (ArnaizVillena 2000), i.e.: Atinas (B.), the door of darkness. Other idiomatic expressions preserved in both ancient Iberian and Basque are shown in chapter 7, section 2.6 of the same reference.

5) Beginning and ending of words are problematic and unless meaning is known, it is very difficult to define them.

Only known and repeated meanings (in several languages) are taken as sound cognate identification.

6) Common and proper names are almost impossible to distinguish. Many proper names come from a common name like in English "Rose" and mainly in Mediterraneans languages like Basque (for males, Bilebai= Circumcision; Gurutz= Cross; Eztegu= Wedding; Lor $-=$ Flower; Aintza $=$ Glory; Sein= Innocent; Lin= Linen; Ama=Mother; Edur $=$ Snow; Gentza $=$ Peace; Deunoro $=$ Saints $;$ Bakarr $=$ Loneliness) and Spanish (for females: Azucena $=$ White Lily; Gloria $=$ Glory; Cruz $=$ Cross; Flor $=$ Flower; Inocencio $=$ Innocent; Lino $=$ Linon; Nieves $=$ Snows; Paz $=$ Peace; Santos= Saints; Soledad $=$ Loneliness. Ancient societies tended to name people with common names (Great Bear, Eagle, Sitting Bull), as it is well known with North American Indians. 
7) Basque language has remained with little modifications throughout time, because invasions have not modified this and other Basque society characteristics (Collins 1989).

8) Basque language was much more widespread than its present day limits (Venemann 2003; Intxausti 1992).

\section{Transliteration and translation hypothesis of Usko-Mediterranean} languages including Iberian.

Iberian-Tartesian, Etruscan and Minoan Linear A have been transliterated and a translation proposed, as referred in (Poulianos 1969; Arnaiz-Villena \& Alonso-García 1999). Basque-Spanish cognate meanings have provided the basis for the translation.

Berber has been distinguished from the Arab contamination by comparison with Basque (Sota et al. 1976; Keretxeta 1990), Iberian-Tartesian (see Chapter 7, of ArnaizVillena 2000) and Arab (Corriente-Cordoba 1977).

The ancient Lybic scripts were studied from (Chabot 1940a; 1940b; 1941; Harden 1971); some of them were written in Punic characters. Directions of the scripts were generally vertical and only assessed by the sense of meaning (Arnaiz-Villena \& Alonso-García 1999).

Etruscan texts were taken from D'Aneusa (1997). Hittite, Sumerian, Eblaic, Elamite, Ugaritic, Egiptian and Guanche texts were taken from the transliterated references of the most recognized World specialists (see references list of ArnaizVillena 2000, chapter 9 pages 210, 245, 246, which may be download from http://chopo.pntic.mec.es/ biolmol/publicaciones/Usko.pdf) (See Arnaiz-Villena \& Alonso-garcia 2000).

\section{Results and Discussion}

\section{Language of Prehistoric Inhabitants of Canary Islands (Guanche)}

Guanches seemed to speak Basque language to the Basque people who went with Castillian soldiers for conquering Canarian Archipelago (Arnaiz-Villena \& Alonso Garcia 2001). We also showed a list of Canarian toponimics with a phonology and semantics similar to Basque language, i.e: Galdar ("Calldera" (Sp.) = Boiler (Eng.)), Telde ("Rebaño" (Sp) = Flock (Eng.)), Teide in Guanche, "Etxeide" = Etxe= Contenedor $(\mathrm{Sp})=$. Container $($ Eng. $)$ and "Aide" = que explota $(\mathrm{Sp})=$. which bursts (Eng.) (Arnaiz-Villena \& Alonso-Garcia 2001). Teide is the highest Canarian Islands 
volcano at Tenerife. "Aguerre" in Basque means "Panoramic View", it was the Guanche name of town "San Cristobal de la Laguna" (Tenerife), from which a panoramic view of two sides of Atlantic Ocean may be seen. Another interesting Guanche word was "Atxano", which was the name for "Year", means "the shadow of the axis", which is a way to measure Sun daily and yearly movements since prehistoric times (Barrios-Garcia 2004). Thus, it is likely that Guanche language was an Usko-Mediterranean one, related with Berber, Basque and extinct Iberian (Arnaiz-Villena \& Alonso-Garcia 1999; Arnaiz-Villena 2001, see Fig. 5).

\begin{tabular}{|c|c|c|c|}
\hline $\begin{array}{l}\text { dentifi- } \\
\text { cación }\end{array}$ & Inscripción Fuerteventura & $\begin{array}{c}\text { Transeripción } \\
\text { Ibero-levantino }\end{array}$ & $\begin{array}{c}\text { Traducción } \\
\text { (vasco y castellano) }\end{array}$ \\
\hline$P 11$ & AVIVYAXYYHSAN & KAMMBAMMKAMMOSKAN & 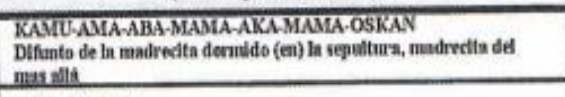 \\
\hline PI2 & $\Lambda S V$ & KasM & 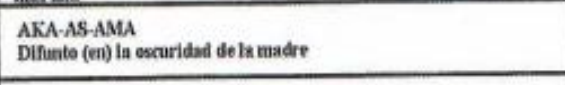 \\
\hline PI2 & IVSIIIIII & ВАMSBABABABABA & 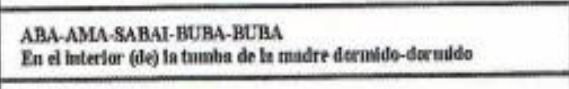 \\
\hline PI2 & $M|x|$ & (1)LKAMBA & 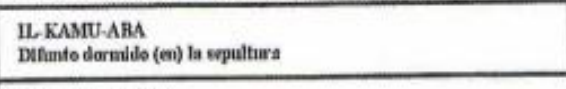 \\
\hline P14 & $(A V \wedge S$ & KEKLMLS & 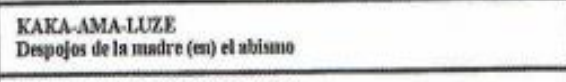 \\
\hline PI4 & $\angle V I I A<A_{1}$ & KAMBABAKAKEKAKA & 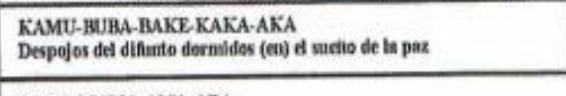 \\
\hline PI 4 & $A\left(V^{\prime \prime}\right)$ & KAKEMMMMA & 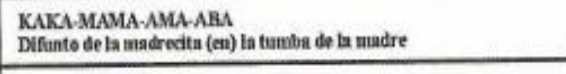 \\
\hline PI5 & $1,1 \Lambda 1$ & BABABALBA & 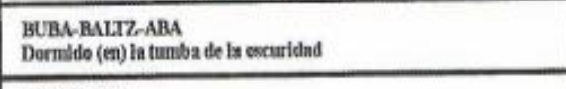 \\
\hline P15 & ISNI & BASNBA & $\begin{array}{l}\text { AASSANABA } \\
\text { (En) A barro de th llamura }\end{array}$ \\
\hline P17 & WWVWNYI & MRAMLMMMKАКАMMBA & 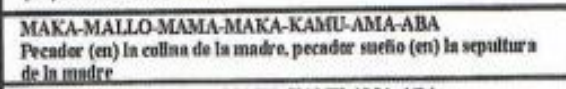 \\
\hline P17 & UAWVWNAN & MKAMLMMMIKAKAMMBA & 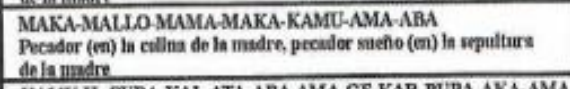 \\
\hline P18 & MIIAXIVEARRIIAN & KAMLBABAKALTABAMGEKARBABAKAM & 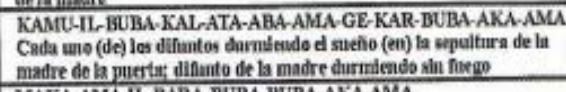 \\
\hline P19 & MVVIIIIN & MKAMLBARBABABABAKAM & 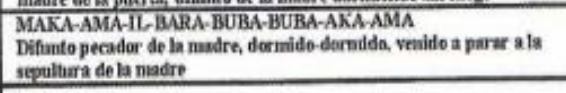 \\
\hline P19 & $\mathbb{R A D} \| \mathrm{MA}$ & RKARBANKA & 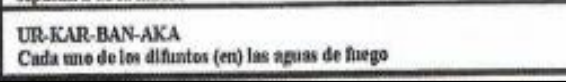 \\
\hline
\end{tabular}

Fig. 5 Proposed of transcription and translation of "Latin" or "Ibero-Guanche" rock inscriptions at Fuerteventura.

A complete work on transcription and translation proposal is found in:https://commons. wikimedia.org/w/index.php?title=File\%3AIberianGuanche inscriptions.pdf\&page=1. (Arnaiz-Villena \& Alonso-García 2001). See Appendix II for English translation 
"Latin" or Ibero-Guanche Inscriptions in Canary Islands.

\section{Fuerteventura and Lanzarote}

Since year 1980 a series of incised lineal rock scripts were observed first at Zonzamas archaeological site in Lanzarote Island close to Arrecife Town (Figs. 1, 3 and 4). Later, more lineal incised rock scripts were found in other Lanzarote places, particularly in high places of volcano cones of the center of the island. Then, more frequent rock scripts were recorded in neighbor Fuerteventura Island (easternmost Canary Islands); scripts were frequently far from the coast and rocks were placed in mountains and ravines. At least 280 lineal rock scripts were collected by Pichler (1995, 2003) at Fuerteventura (Fig. 5). These lineal scripts were called "Latin" but they have never been translated from Latin; however, they were transcribed by using Iberian semisyllabary (Gomez-Moreno 1949; 1962) and a hypothesis of translation was put forward (Arnaiz-Villena \& Alonso-Garcia 2001). This is because these authors named these inscriptions as "Ibero-Guanche".

\section{Tenerife, El Hierro, La Gomera, Gran Canaria and La Palma Islands}

This type of incise lineal inscriptions may exist but be unnoticed and not seen in other Canary Islands more humid and grass covered than Lanzarote and Fuerteventura. However reports of their existence in all other five bigger and most populated islands are recorded. Also (Nowak 1994) described another "IberianGuanche" inscription in the westernmost El Hierro Island very early, at the same time that Pichler recollected his work in Fuerteventura for being published (Pichler 1995). It is striking that Canarian and Spanish Archaeology have ignored these "IberianGuanche" inscriptions.

Also, it was found another rock with lineal "Iberian-Guanche inscription in "Cañada de Ovejeros". Tenerife Island (Fig. 6) and it was recorded as "neo-punic" by some authors (Gonzalez-Anton et al. 2009); however, Iberian characters may be observed (see Appendix I) In addition, other panel of inscriptions has been found on a polished stone rock (The Rock of the Dead) in Tenerife (Arnaiz-Villena et al. 2019b).

In Fig. 7 a wooden handle from La Gomera Island "El Cerrillal" site (Navarro, 1996, page 266, Fig. 3) is represented. Letters Y and V are repeated in Iberian semisyllabary ( $\mathrm{M}=\mathrm{Y}=\mathrm{V}$ letters) (see Appendix I). If vowels have been omitted as used to be in North Africa and Canary Islands ancient lybic languages (Arnaiz-Villena \& Alonso-Garcia 2001) a possible translation may be a repeated "(A) M (A) i.e.: repeated 
invocation to "AMA", Mother Godness. (Gonzalez-Anton et al. 2009). Similar inscriptions and translations have been proposed in Fuerteventura Ibero-Guanche scripts (Arnaiz-Villena \& Alonso-Garcia 2000).

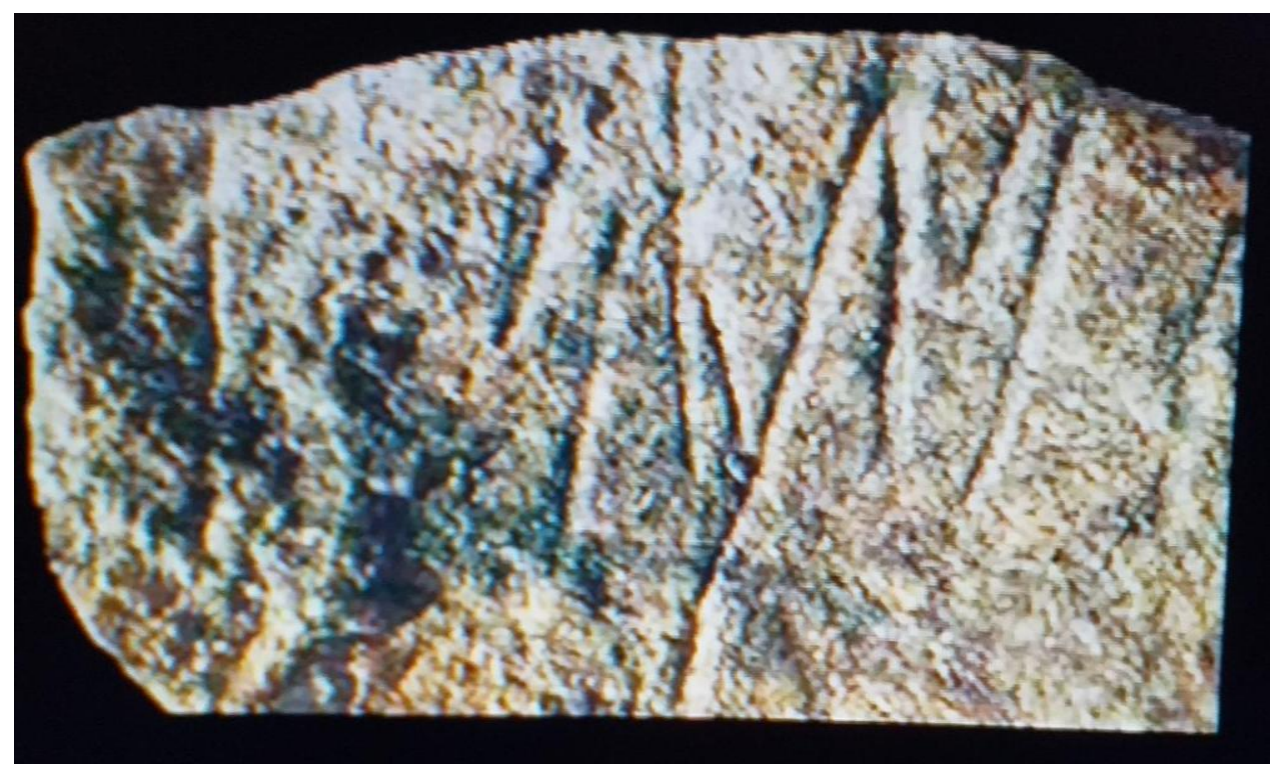

Fig. 6 Ibero-Guanche script, Cañada de Ovejeros, Tenerife. This lineal "Latin" or "Ibero-Guanche" inscription was published like" neo-punic" in (Gonzalez-Anton et al, 2009).
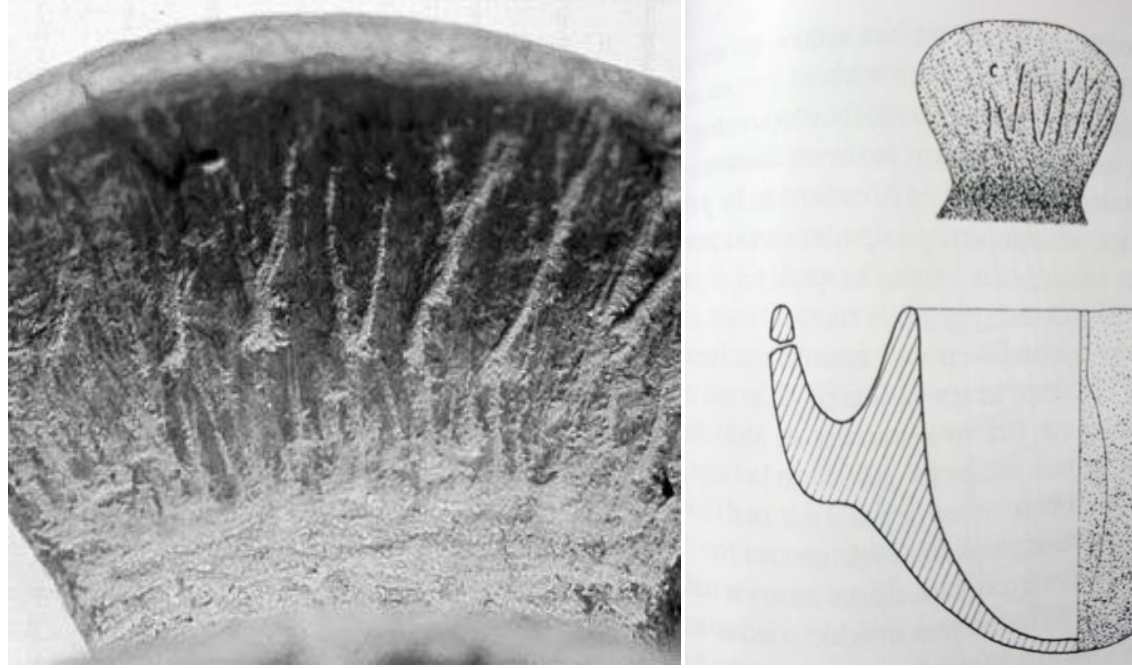

Fig. 7 Wooden cup with handle. La Gomera Latin / Ibero-Guanche characters (Navarro et al. 1996, pp 281) 
In Fig. 8, a panel of drawings is depicted from, "Laja de la Mula", a bed at Mogan Town (South Gran Canaria). Again "Y" and "V" = M (Appendix I) may be seen (repeated invocation again to (A) M (A) Mother Godness) (Cuenca-Sanabria 1996).

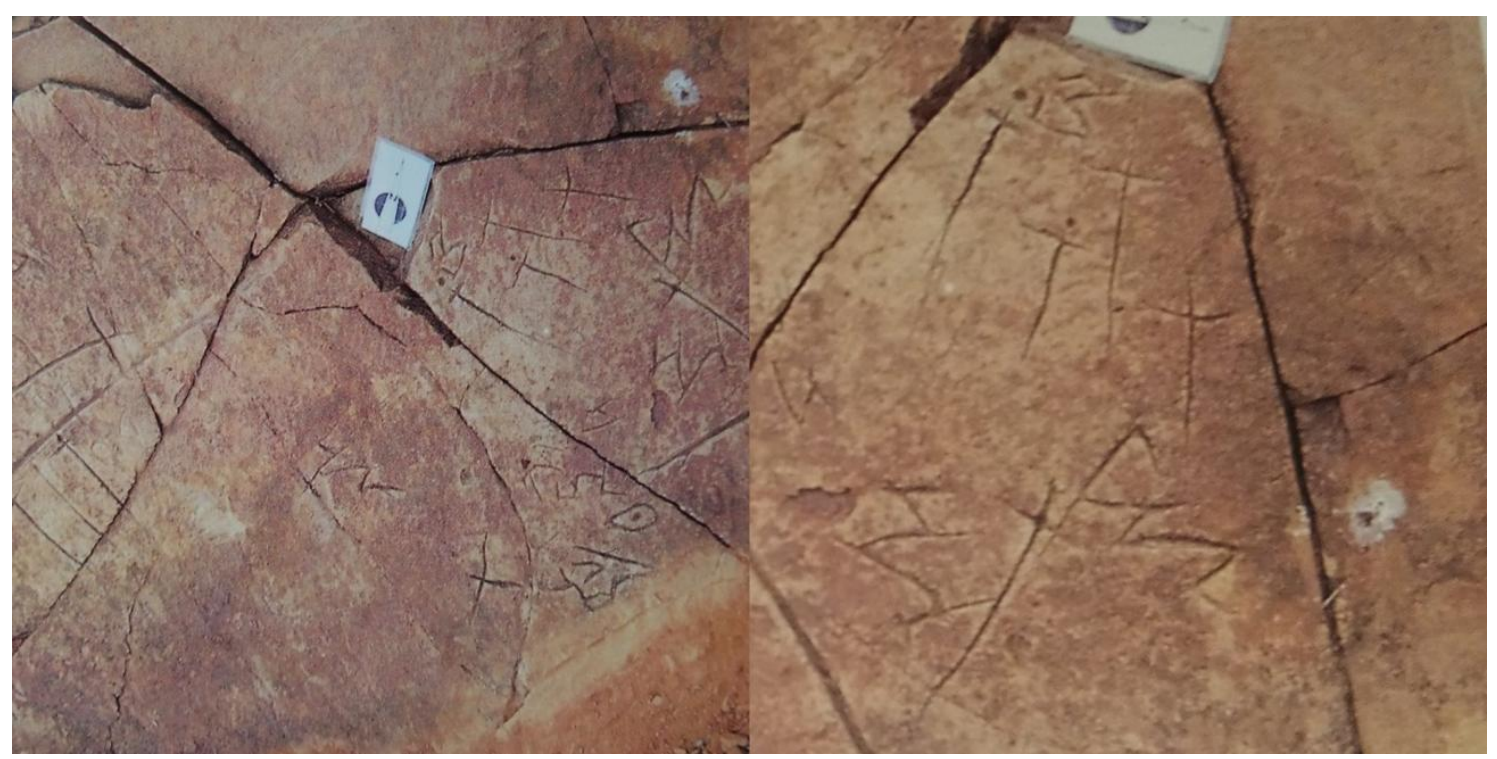

Fig. 8 Gran Canaria (Mogan)

Latin / Ibero-Guanche characters (Cuenca-Sanabria et al. 1996, p 221)

Finally identical rock incise lineal signs to that of Lanzarote / Fuerteventura, (which may be Iberian) have been reported in La Palma Island (Pais 2008; Pais 2010 in: http://www.cabildodelanzarote.com/patrimonio/VIIcongreso/ponencias/jueves/Las\%20i ntervenciones\%20rupestres\%20de\%20los\%20benahoaritas.\%20Jorge\%20Pais.pdf

Therefore, lineal possible Iberian-Guanche scripts do exist in all seven most inhabited Canary Islands: these rock incised Iberian-Guanche signs are present in all Canary Islands.

\section{Origin of Iberian-Guanche Inscriptions: Africa and Europe}

These Canarian incise linear rock inscriptions are similar to Iberian semisyllabary (Appendix I) and another very similar ones have been found in Tunisia (Bonifay 2004). Probably, many other lineal Iberian-Guanche inscriptions have not been noticed in African archaeology sites and also may be earthed under Sahara Desert. Lineal incised rock inscriptions have also been found in western, central and eastern Europe (Runes). Some North Italian-Austrian pre-Latin "languages" have even the same signs than Ibero-Guanche scripts: Italian old scripts (Venetic, Raetic, Lepontic) (Fig. 9). Also Eastern Europe (https://en.wikipedia.org/wiki/Vin\%C4\%8Da_symbols 
Vinca inscription) has similar scripts to that of Ibero-Guanche ones dated since 5,000 years BC (Figs. 9, 10) (and also to Iberian semi-syllabary). Other lineal incise scripts on different supports are Etruscan (Arnaiz-Villena \& Alonso-Garcia 2008) and some other scripts found in North Mediterranean, including Greece (see Fig. 9, 10) from the fifth millennium BC. Thus, all these incise lineal rock inscriptions should be taken into account to study origins, cultural and precursor role of Iberian semi-syllabary, IberoGuanche inscriptions and our own alphabet, so origins. Particularly, solve which is the oldest type of lineal inscriptions and revise extensively our so called Latin alphabet origin and timing and origin of languages. In this respect, relationship with ancient berber lineal scripts should also be studied (Hachid 2000, 2003).

\begin{tabular}{|c|c|c|c|c|c|}
\hline $\begin{array}{c}\text { VENETTC } \\
\text { Este }\end{array}$ & $\begin{array}{l}\text { EAST RAETIC } \\
\text { Magre }\end{array}$ & $\begin{array}{l}\text { WEST RAETIC } \\
\text { Bolsane-Santmo }\end{array}$ & $\begin{array}{l}\text { CAMUUNIC } \\
\text { Soodro }\end{array}$ & $\begin{array}{l}\text { LEPONTIC } \\
\text { Lugano }\end{array}$ & \\
\hline$A \cap A$ & $A \wedge A \wedge$ & $A \wedge A \wedge$ & $\begin{array}{l}\text {. } \\
H\end{array}$ & A7 & a \\
\hline$>(=0)$ & & $>0$ & $>(=g)$ & & $\mathrm{c} g$ \\
\hline 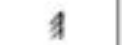 & is & $\geqslant$ & 131 & 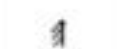 & e \\
\hline 4 & $\lambda$ & 4 & 패 & & $\mathbf{v}$ \\
\hline$\not X(=d)$ & $\not x(-d)$ & 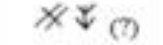 & $Y_{\lambda}$ & $\not x$ & $z$ \\
\hline 日月吊 & 日月 & $\$$ & HHIII & & h \\
\hline$\odot_{(=t)}$ & & & $x \cdots 00$ & $\odot$ & $\theta$ \\
\hline 18 & 1 & 1 & 11 & 1 & i \\
\hline$x$ & $x$ & $x$ & $(\mid \sqrt{ } / 3) \times$ & $x$ & $\mathrm{k}$ \\
\hline งt & in & $\checkmark$ & J11 L & J & 1 \\
\hline$m \sim$ & M & $M$ & YM & $m M$ & $\mathrm{~m}$ \\
\hline $4 \mathrm{H}$ & 4 & 4 & ory & $4 n$ & $\mathrm{n}$ \\
\hline & & & 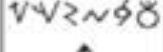 & & $o / u$ \\
\hline & & & 0 & 08 & - \\
\hline & 717 & ${ }^{\circ}$ & UटC4 & 1 & $\mathrm{p}$ \\
\hline & $M A$ & $M$ & 89 & $\bowtie \bowtie$ & 5 \\
\hline 205 & 04 & 044 & 40 & व & $\mathrm{r}$ \\
\hline $23 \xi$ & $x 2$ & 2ई & $\Downarrow \vee *$ & $5 \xi$ & s \\
\hline$\times 1$ & $x \times t$ & $x$ & $T+1 t+1\}$ & $x$ & t \\
\hline$V \wedge$ & $\hat{\imath}$ & $\checkmark$ & VAYh & v & $\mathrm{u}$ \\
\hline $8(-10)$ & $1 \varphi^{\circ}$ & $1 \varphi^{\circ}$ & $\underset{* * \infty}{\phi}$ & & $\stackrel{\varphi}{t s p \mathrm{pp}}$ \\
\hline & & & $\uparrow ג \lambda \uparrow$ & & P \\
\hline 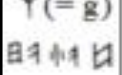 & $Y V$ & $Y \vee$ & & V & $x$ \\
\hline & $\uparrow \uparrow \uparrow \& \&$ & & & & $\mathrm{t}^{\prime}$ \\
\hline
\end{tabular}

Fig. 9 Old Italic Scripts. https://www.omniglot.com/writing/olditalic.htm. North Italic scripts have very similar characters to Ibero-Guanche canarian scripts (Raetic, Venetian, Lepontic). Also Etruscan language is written in lineal similar characters, like Iberian language is (Arnaiz-Villena \& Alonso-Garcia 2001) 


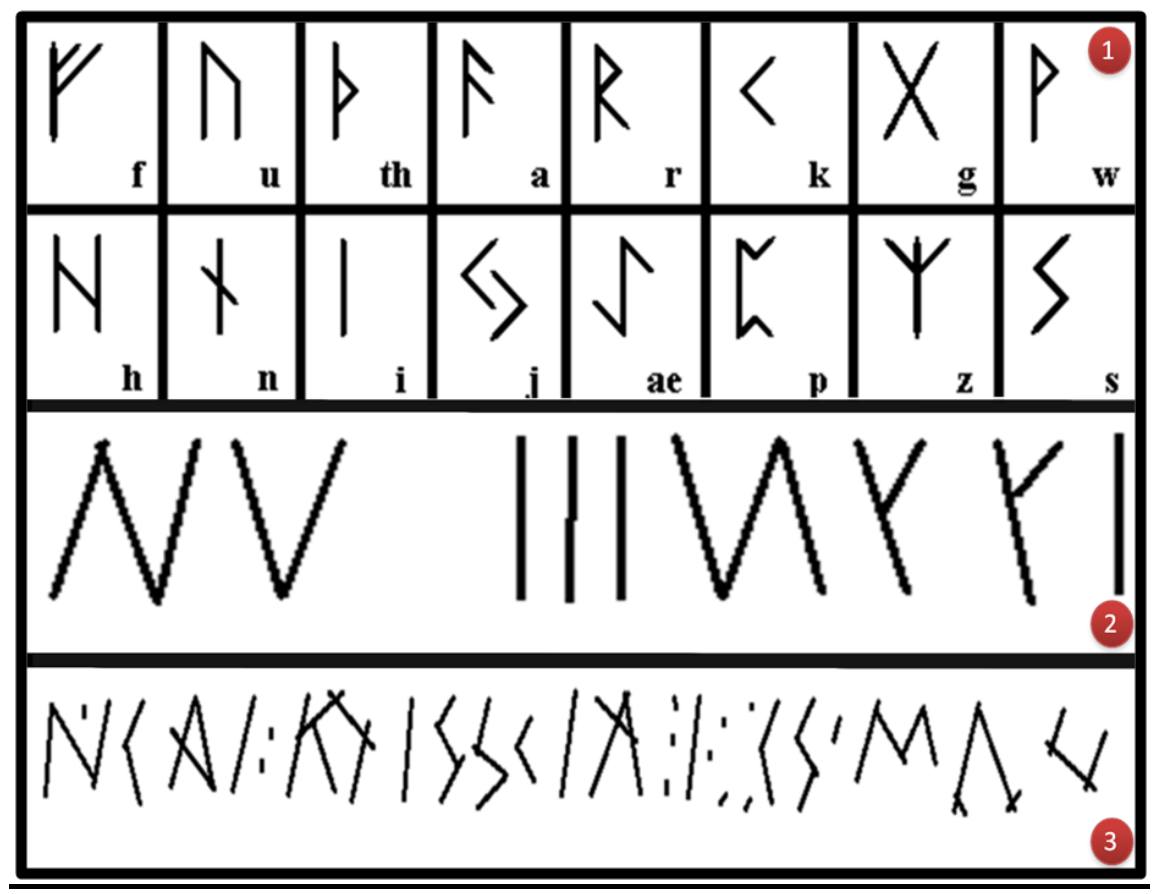

Fig. 10

1) Runic inscriptions have been found throughout Europe from the Balkans to Germany, Scandinavia and the British Isles. https://www.omniglot.com/writing/runic.htm

2) Gradeshnitsa Tables (Bulgaria) 4,500 years BC.

https://en.wikipedia.org/wiki/Gradeshnitsa_tablets.

3) Sitovo inscription, Plovdiv (Bulgaria ,3,000 years BC, Alexander Peev).

https://en.wikipedia.org/wiki/Sitovo_inscription.

\section{Genetics}

It was established long time ago Africa to Iberia gene flow, probably occurring in both directions, during Prehistory. These conclusions were both reached with autosomic (paternal and maternal, Arnaiz-Villena et al. 1999 from Madrid, Spain) and other genetic markers by different and not related groups at different times (Currat el al. 2010 from Barcelona, Spain, Bertranpetit's; Botigue et al. 2013 from Geneva, Switzerland, directed by Sanchez-Mazas). Recently, it has been confirmed by an Italian group directed by Barbujani (Gonzalez-Fortes et al. 2019). These three groups were long established and internationally reputed. Fregel et al. (2018), a Canarian group at La Laguna University, also found ancient genetic relationship between Africa and Europe. They also found what they call specific Canary Island haplogroups (Fregel et al. 2019): this is a poorly based conclusion, since negative results do not mean that "specific" Canarian haplogroups will not be found in other places. In addition, population genetics structure according to geography does not exist for mtDNA haplogroups; assigning 
individuals with a particular mtDNA haplogroup to a World region is not possible. This has been found by using a big non- ancient mtDNA database (Emery et al. 2015).

Thus, Iberian and North African gene pool is very similar (Arnaiz -Villena et al. 1999; Currat el al. 2010; Botigue et al. 2013 and Gonzalez-Fortes et al. 2019). In this context, discussing whether Canary Islands gene pool is more similar to that of North Africa or Iberia is useless. In fact, genetics by itself is not useful to establish relatedness between populations which must be used together with other Anthropology characters like Culture, Archaeology, Language etc (Farrujia et al. 2009).

"Latin" rock inscriptions are not "Latin", but are lineal Iberian scripts.

The so called "Latin" scripts are lineal characters, which have not yet been translated. If there were Latin inscriptions, they would have been translated. The following facts discard that these scripts represent Latin language:

1. No translation has been formally proposed for these so called "Latin" characters since Pichler published his compilations on Fuerteventura inscriptions (Pichler 1995; 2003).

2. Arnaiz-Villena \& Alonso-Garcia $(2001 ; 2007)$ recognized that this lineal script were Iberian semi-syllabic (Fig. 2) (Gomez-Moreno, 1949; 1962) and proposed translations that mostly fit with other translations put forward by these authors based on Basque-Iberian equivalences.

(https://commons.wikimedia.org/w/index.php?title=File\%3AIberian-

Guanche inscriptions.pdf\&page $=1$ )

At present, Basque-Iberian close relatedness is again accepted since Basque and Ancient Iberian numerals are identical (Ferrer i Jane 2009; Orduña 2005; 2013).

3. Fuerteventura lineal scripts lack the following letters which are basic in Latin writing: "C", "Q" and " $H$ " (it is $H=O$ in old Iberian writing) (Pichler 2003). "A" ( $A$ ) is not correct: it represents sound "KA" in Iberian. (Fig. 2)

4. Occlusive consonants apparently do not exist or they are very scanty (Pichler 2003): "B" has been only found 3 times, and even it could not be " $\mathrm{B}$ ".

"P" has not been found. "T" has not been found. "C" (with a sound similar to "K") in Latin has not been found. " $\lambda$ " is used for $=$ "KA" in this particular Canary Islands Iberian scripts, as it is found in Iberia. It is remarkable that occlusive consonants due exist in Iberian language in form of syllables (Appendix I). 
5. Lineal Canarian "Latin" signs " $\lambda$ " and " $\mid$ ", (wrongly translated to as " $A$ " and "I", as if it was Latin) represent $25 \%$ and $16 \%$ respectively of Fuerteventura scripts (Pichler 2003). This is a clear excess of vowel letters and signs particularly strange to ancient North African/Mediterranean languages in which vowels are usually not written.

6. Linking contiguous signs are more often found in these Canarian "IberianGuanche" inscriptions than in Iberian scripts found in Iberia and southern France. This phenomenon also occurs with Canarian-Lybian inscriptions (Arnaiz-Villena \& AlonsoGarcia 2001). This may be due to the effort to make all inscriptions in hard basaltic rocks which sometimes seem to have been polished, see Fig. 4 from a Lanzarote rock script and another script from Tenerife (Arnaiz-Villena et al. 2019b). Writing support seems to have been hard stones in Canary Islands with engraving difficulties.

7. Lack of some Iberian characters in the obtained inscriptions (Fig. 5) (Pichler 2003) and some others differential characters in Ibero-Guanche inscriptions with respect to Iberian scripts (Appendix I). Commented in the present paper may be due: a) to the relative small "corpus" of available inscriptions or b) to Canary Islands "IberianGuanche" scripts being more primitive and the origin of Iberian semi-syllabary, c) "Iberian-Guanche" scripts may represent a local modified Iberian, d) It is a variation of linear scripts, including Iberian which is found in Europe (Runes, Old Latin languages: Raetic, Lepontic, Venetic, East European scripts like Vinca (Serbia), Gradeshnitsa and Sitovo (Bulgaria). These 3 Letters dated $4^{\text {th }}-5^{\text {th }}$ millennium BC. (see Figs 9 and 10). Thus African Moroccan and Western Sahara territory should be carefully searched for existence of this type of lineal writing which may have been disregarded as "stone scratches" if not specifically looking for it. In fact, similar scripts have been found in Tunisia (Bonifay 2004). Prehistoric artifacts have been found at Lanzarote at the beginning of the $1^{\text {st }}$ millennium BC and other authors put them back to Bronze Age (Atoche Peña \& Ramirez Rodriguez 2009).

8. The case of Iberian-Guanche scripts being the most ancient writing system of Canary Islands is favored because when Lybic rock scripts are found overlapping with "Iberian-Guanche" rock scripts in the same rock panel, Lybic inscriptions are engraved over Ibero-Guanche inscriptions (Personal observation and Medina \& Arnaiz-Villena 2018b).

9. Language of Guanches-Canarian First Inhabitants as met by Basque soldiers in Spain war to conquest Islands noticed "that they spoke Basque". A Basque Bishop was sent to teach them Christianity (Krutwig 1978). Also many Guanche names and 
Canarian toponimics are easily translated to Basque (Arnaiz-Villena \& Alonso-Garcia 1998; 2001). However, original language is officially not known, but very likely is close to North African ones. Basque and Berber are related languages (Arnaiz-Villena \& Alonso-Garcia 2001).

10. Pre-Romanic and Pre-Punic cultural environment: close African coast pyramids, controversial Guimar pyramids, (Fig. 2), megalithic structures like Western Sahara cromlech and other artifacts (Clarke \& Brooks 2018), and Lanzarote Lunisolar Calendar "Quesera"/Cheeseboard (Fig. 11). Also, cart-ruts have been described in Lamzarote, which are not Roman or Punic and may be prehistoric as they are in Malta (Arnaiz-Villena et al. 2018, 2019a).

11. If "Ibero-Guanche" scripts are abundant and widespread throughout Canary Islands, it is the first solid evidence that Guanches had the same culture at one stage and that they could navigate.

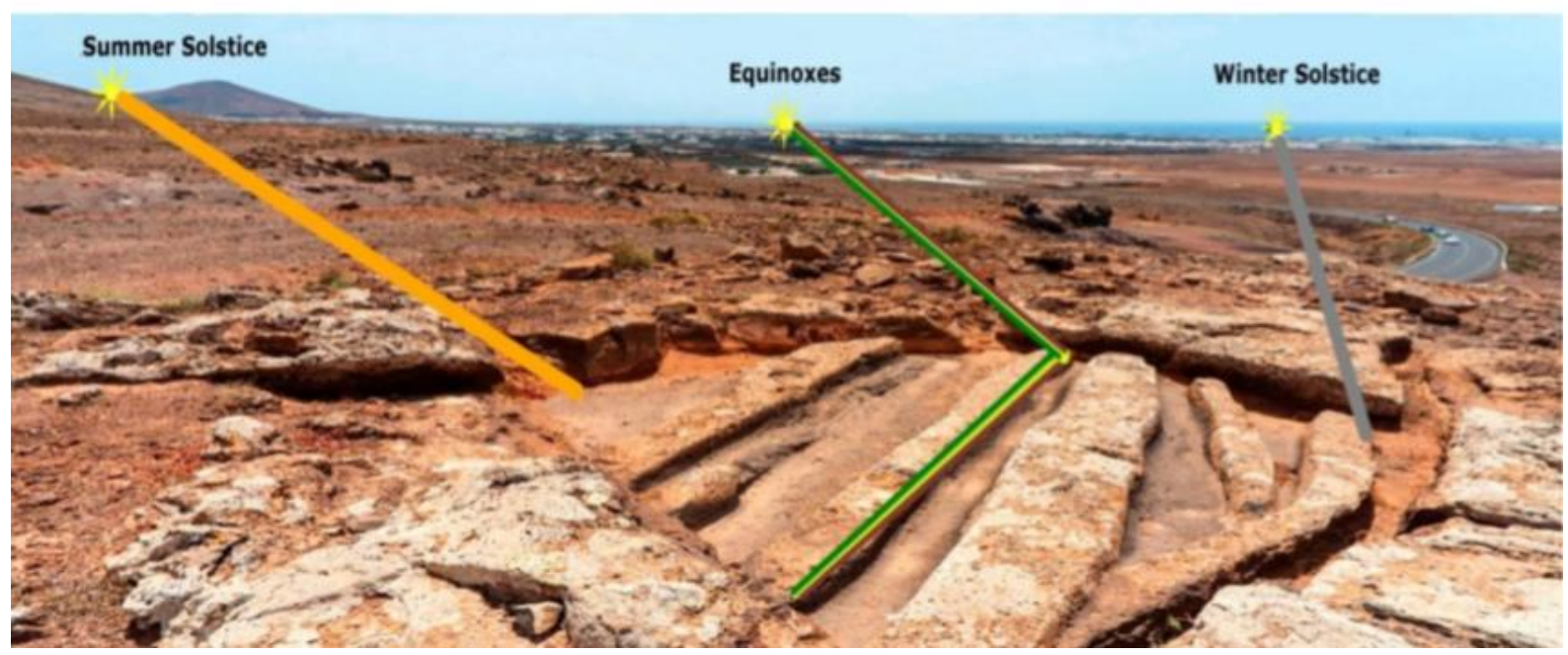

Fig. 11 Sunrise at Summer Solstices, Autumn/Spring Equinoxes and Winter Solstice from a "Quesera" observer (left to right). Photography from "Quesera" of Zonzamas.

Left: Sun rises (2014 AD) between Maneje and Tahiche mountains at Summer Solstice (orange line). It is possible that if "Quesera" is ancient enough, an observer from this point might have seen Sun rising at Tahiche mountain slope or vertex in Antiquity because Ecliptic obliquity is diminishing about 0.47 arch seconds per year at present times.

Middle: Sun rises at middle sea horizon, both at Autumn and Spring Equinoxes (green line).

Right: Sun rises at right sea horizon at Winter Solstice (grey line). Sunrises complete a yearly azimuth arch between $62^{\circ}$ and $117^{\circ}$ degrees going from June 21 st to December 21st and back.(Medina \& Arnaiz-Villena 2018 a, b) 


\section{Appendix I}

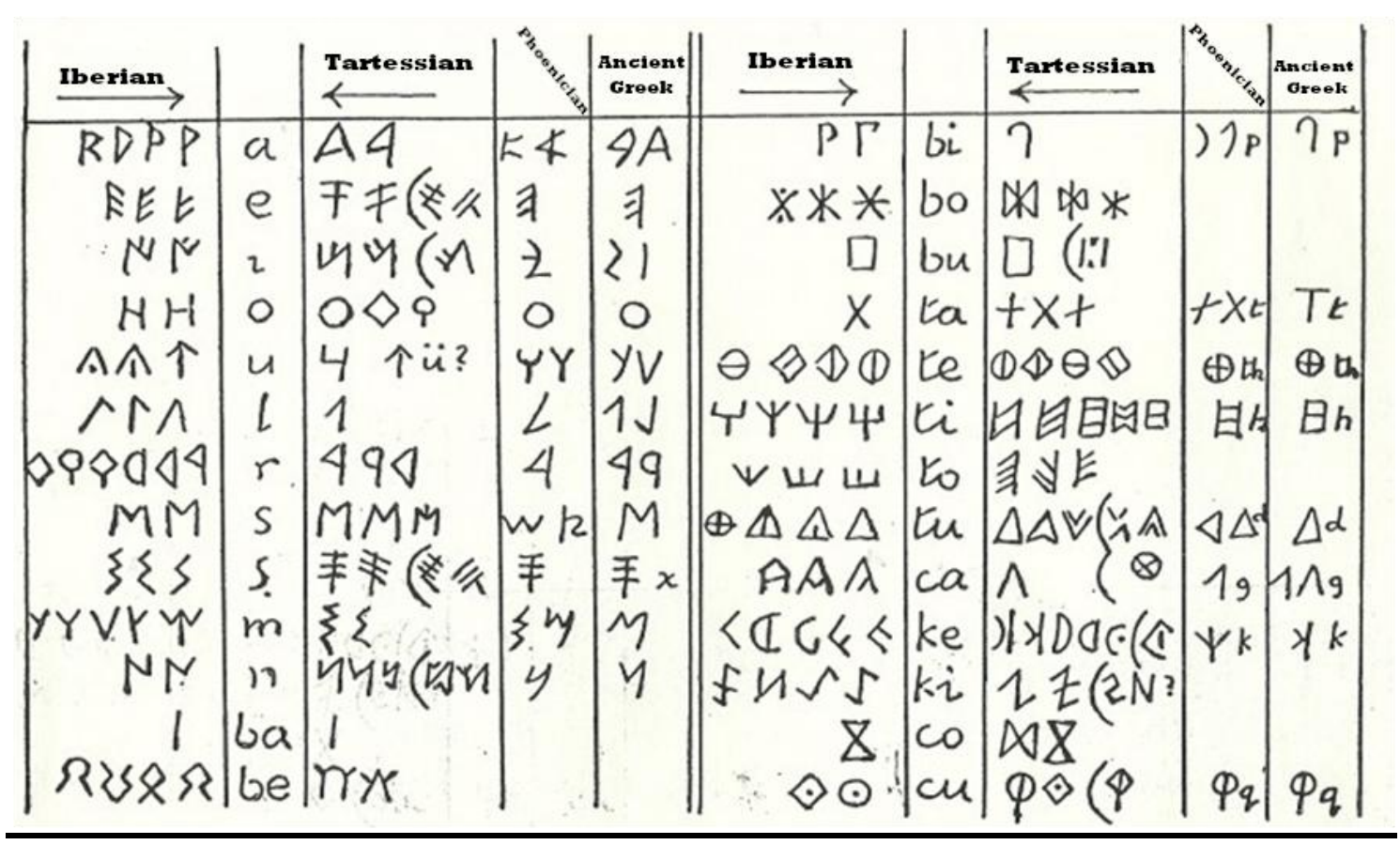

Iberian-Tartessian semi-syllabary (Gómez Moreno 1949; 1962); comparison with other language scripts

\section{Appendix II}

\begin{tabular}{|c|c|c|}
\hline No & Identification & Translation \\
\hline 1 & $\mathrm{PI} 1$ & Dead of my mother sleeping at tomb, my mothers of the other world. \\
\hline 2 & $\mathrm{PI} 2$ & Dead in mother darkness. \\
\hline 3 & $\mathrm{PI}$ & Inside tombs of mother sleeping-sleeping. \\
\hline 4 & $\mathrm{PI} 2$ & Dead sleeping in tomb. \\
\hline 7 & $\mathrm{PI}$ & Remains of mother in abyss. \\
\hline 8 & $\mathrm{PI}$ & Dead in my mother in mother tombs. \\
\hline 9 & $\mathrm{PI}$ & Sleeping in the darkness tomb. \\
\hline 10 & $\mathrm{PI5}$ & In the mud of the plain. \\
\hline 11 & $\mathrm{PI}$ & Sinner in the mother hill; sinner sleeping in mother tombs. \\
\hline 13 & $\mathrm{PI}$ & Sinner in the mother hill; sinner sleeping in mother tombs \\
\hline 14 & $\mathrm{PI}$ & Each dead sleeping/sleeping in the door mother; mother dead sleeping \\
\hline 15 & $\mathrm{Pl}$ & without fire. \\
\hline 16 & $\mathrm{PI9}$ & Dead sinner of the mother, sleeping/sleeping; has come to mother tomb. \\
\hline 17 & $\mathrm{PI9}$ & Each of the dead in fire waters. \\
\hline
\end{tabular}

English version of translation hypothesis (see Fig. 5). (Arnaiz-Villena \& Alonso-

Garcia 2001). 


\section{Acknowledgements}

We thank University Complutense of Madrid for its continuous support. AA-V had PI18/00720 gant from Ministerio de Ciencia, Innovacion y Universidades and FEDER funds.

Conflicts of Interest: The authors declare no conflict of interest.

\section{References}

Arnaiz-Villena A. \& Alonso-García J. (1st edition) 1998. El Origen de los Vascos y otros Pueblos Mediterráneos (2 edición). Editorial Complutense. Madrid (Spain). | New Edición 2011. Ed. Visión Libros. Madrid (Spain).

Arnaiz-Villena A., Martinez-Laso J., Alonso-Garcia J. 1999. Iberia: Population Genetics, Anthropology and Linguistics. Human Biology 71: 725-743.

Arnaiz-Villena A. 2000. Prehistoric Iberia: Genetics, Anthropology and Linguistics. Chapter 9: The Usko-Mediterranean Languages. Ed. Kluwer. Plenum Press. New York (USA). http://chopo.pntic.mec.es/ biolmol/publicaciones/Usko.pdf.

Arnaiz-Villena A. \& Alonso García J. 2001. Egipcios, Bereberes, Guanches y Vascos. Ed. Visión Libros. (3rd Edition 2011) ACCI. Madrid (Spain).

Arnaiz-Villena A., Martinez-Laso J., Alonso-Garcia J. 2001. The correlation between languages and genes: the Usko-Mediterranean peoples. Human Immunology 62:10511061.

Arnaiz-Villena A., Gomez-Casado E. \& Martinez-Laso J. 2002. Population genetic relationships between Mediterranean populations determined by HLA allele distribution and historic perspective.

Tissue Antigens 60: 111-121

Arnaiz-Villena A. \& Alonso-García J. 2007. Diccionario Ibérico-Euskera Castellano. Ed. Fundación Estudios Genéticos y Lingüísticos | Nueva Edición 2012 Ed. Visión Libros. Madrid (Spain).

Arnaiz-Villena A. \& Alonso-Garcia J. 2008. Diccionario Etrusco-Euskera-Castellano. Ed. Vision Libros. Madrid (Spain). 
Arnaiz-Villena A., Muñiz E., Campos C., Gómez-Casado E., Tomasi S., Martínez Quiles N., Martín-Villa M., Palacio-Gruber J. 2015. Origin of Ancient Canary Islanders (Guanches): presence of Atlantic/Iberian HLA and Y chromosome genes and Ancient Iberian language. Int. J. Mod. Anthrop. 8: 67-93.

Arnaiz-Villena A., Carballo A., Juarez I., Muñiz E., Campos C., Tejedor B., MartínVilla M., Palacio-Gruber J. 2017. HLA Genes in Atlantic Celtic populations: Are Celts Iberians? Int. J. Mod. Anthrop. 10: 50 - 72.

Arnaiz-Villena A., Medina M., Palacio-Gruber J., Lopez-Nares A., Ruiz-del-Valle V.2018. Malta and Lanzarote (Canary Islands, Spain) -ruts and Rock Prehistoric Calendar at Zonzamas, Lanzarote-“Quesera"/Cheeseboard-. Int. J. Mod. Anthrop. 11: 214-231.

Arnaiz-Villena A., Medina M., Lopez-Nares A., Rodriguez-Rodriguez, J., Ruiz-delValle V. 2019a. Cart-ruts in Lanzarote (Canary Islands, Spain) and Malta: first evidence of dating supported by dated ceramics. Int. J. Mod. Anthrop. 2: 115-140.

Arnaiz-Villena A. 2019b. The Rock of the Dead: A New" Latin" or "Iberian-Guanche" Inscriptions found in Tenerife Is. (Canary Islands, Spain). Int. J. Mod. Anthrop. 2: 214232

Arribas A. 1976. Los Iberos. Ed. Ayma. Barcelona (Spain).

Atoche Peña P. \& Ramirez Rodriguez M.A. 2009. Manifestaciones rupestres protohistoricas de Lanzarote pp 187-209, in "Rock carvings of the European and African Atlantic Façade". BAR 2043, Archaeopress, Oxford (UK).

Barrios García J. 2004. Sistemas de numeración y calendarios de las poblaciones bereberes de Gran Canaria y Tenerife en los siglos XIV-XV. Thesis doctoral. Universidad de La Laguna, Tenerife, Islas Canarias (Spain). http://www.etnomatematica.org/publica/trabajos_doctorado/tenerife.pdf

Barrios Garcia J., Valencia Alfonso V. and Brito Mayor A. 2018. Investigaciones arqueo astronómicas en Gran Canaria. La recamara equinoccial de la cueva de la virgen de la Candelaria (Tara, Telde) XXIII Coloquio de Historia Canario Americana. Las Palmas, Gran Canaria. (Islas Canarias, Spain), 1-23.

Bonifay M. 2004. Etudes sur la ceramique romaine tardive d'Afrique. BAR International Series 1301 (Oxford, UK). 
Botigue L R., Henn B M., Gravel S., Maples, B K., Gignoux, C. R., Corona E., Atzmon G., Burns E., Ostrer H., Flores C., Bertranpetit J., Comas D., Bustamante C D. 2013. Gene flow from North Africa contributes to differential human genetic diversity in southern Europe. Proceedings of the National Academy of Sciences 110 (29): 11791-6.

Chabot J.B., Beguinot F. 1940a. "Apunti di Epigr". Libicadansl'Africa italiana. Mencionada en Recueil des Inscriptions Libyques. Imprimerie Nationale, Paris (France).

Chabot J.B. 1940b. Recueil des Incriptions Libyques (fascicule premier). Imprimerie Nationale. París (France).

Chabot J.B. 1941. Recueil des Incriptions Libyques (fascicule second). Imprimerie Nationale. París (France).

Clarke J., Brooks N.2018. The Archaeology of Western Sahara. Oxford Books. Oxford (UK).

Collins R. 1989. Los Vascos. Madrid. Alianza Universidad (Spain).

Corriente-Cordoba F. 1977. Dictionaire Kabyle-Français. Selaf. Paris. (France).

Cuenca-Sanabria J. 1996. Las manifestaciones rupestres de Gran Canaria. In: Manifestaciones rupestres de las Islas Canarias-. Dirección General de Patrimonio Histórico. pp. 133-222. Sta Cruz de Tenerife (Islas Canarias, Spain)

Currat M.; Poloni E.S.; Sanchez-Mazas A. 2010. Human genetic differentiation across the Strait of Gibraltar. BMC Evol. Biol. 10: 237-243.

D’Aneusa A. 1997. Crestomazza Etrusca Epigrafica. Paideta Editrice. Brescia. (Italy).

Emery L.S., Magnaye KM., Bigham AW., Akey JM., Barmashod M.J.2015. Estimates of continental ancestry vary widely among individuals with the same mtDNA haplogroup. Am J Hum Genet 96: 183-193.

Farrujia de la Rosa A. J., Pichler W., Rodrigue A., Garcia-Marin S. 2009. Las Escrituras Libico-Bereber y Latino-Canaria en la Secuenciacion del poblamiento de las Islas Canarias. El Museo Canario. LXIV. pp. 9-50 (Gran Canaria, Spain). 
Fregel R., Mendez F.L., Bockbot Y., Martin-Socas D., Camalich-Massieu M.D., Santana J., et al. 2018. Ancient genomes from North Africa evidence prehistoric migrations to the Maghreb from both the Levant and Europe. PNAS. 26: 6774-6779.

Fregel R., Ordoñez A.C., Santana-Cabrera J., Cabrera V.C., Velasco-Vázquez J., Alberto V., et al. 2019. Mitogenomes illuminate the origin and migration patterns of the indigenous people of the Canary Islands. PLOS ONE. 14(3)

10.1371/journal.pone.0209125.

Ferrer i Jane J. 2009. El Sistema de Numerales Iberico: Avances en su Conocimiento. Acta Paleohispanica X. Palehispanica. 9: 451-479.

Gómez Moreno M. 1949. Las lenguas hispánicas. Discurso de recepción en la Real Academia Española. Madrid (Spain).

Gómez Moreno M. 1962. La escritura bardulo-turdetana. Ed. Primitiva Hispánica. Madrid (Spain).

Gonzalez-Antón R., Arco Aguilar M.C., Rosario Adrian M.C., González Ginovés L., Benito Mateo C., Balbin Behrmann R., Bueno Ramirez P. 2009. Grabados y poblamiento prehistórico en el archipiélago canario. Edited by Balbin Behrmann R., et al. BAR International Series 2043. "Grabados rupestres de la fachada atlántica europea $\mathrm{y}$ africana. Rock Carving of the European and African Atlantic Façade". Publisher Archaeopress, p.p. 211-229 (Oxford, UK).

Gonzalez-Fortes G., Tassi E., Trucchi E., Henneberger K., Paijmans J.L.A., Diezdel.Molino D., et al. 2019. A western route of prehistoric human migration from Africa into the Iberian Peninsula. Pro Royal Soc B. DOI: 10.1098/rspb2018.2288.

Hachid M. 2000. Les premier berebers entre Mediterranee, Tassili et Nil. Edited by EDISUD. Aix-en-Provence (France).

Hachid M. 2003. Postface de L'ouvrage "Aux Origines de L'ecritureau Maroc. Corpus des Inscriptions Amarcighes des Sites D'art Rupestre du Marok”. Edited by: Skounti A., Lemdjidi A. and Nami M. Publication de L'Institute Royal de la Culture Amazighe. CEALPA, Rabat (Morocco).

Harden D.1971. The Phoenicians. Ed: Penguins Books, London. (UK). 
Hernandez-Bautista R., Perera A. 1983. Newspaper "La Provincia" (Canary Islands, Spain).

Hajjej A., Almawi W.Y., Arnaiz-Villena A., Hattab L., Hmida S. 2018. The genetic heterogeneity of Arab populations as inferred from HLA genes.

PLoS ONE 13(3): e0192269. DOI: https:// doi.org/10.1371/journal.pone.0192269.

Intxausti J. 1992. Euskera, la lengua de los vascos. Elkar-Eusko Jourlaritza. DonostiaSan Sebastian (Spain).

Keretxeta J. 1990. Diccionario Amaia de la lengua vasca. Madrid. Ed. Ernesto Gutierrez (Spain).

Krutwig F. 1978. Garaldea. Ed Txertoa. San Sebastian (Spain).

Medina M., Arnaiz-Villena A. 2018a. A Lunisolar Prehistoric Calendar in Lanzarote Island: "La Quesera" (Cheeseboard) from Zonzamas. In. J. Mod. Anthrop 2: 147-161.

Medina M., Arnaiz-Villena A. 2018b. The Moon: in Prehistoric Lunisolar Rock Calendar "Quesera"-Cheeseboard- at Lanzarote, Canary Islands, Spain. Int.J.Mod.Anthrop 2: 182-212.

Navarro M. 1996. Las manifestaciones rupestres de La Gomera. In: Manifestaciones rupestres de las Islas Canarias 2, pp.253-398. Dirección General del Patrimonio Histórico. Vice consejeria de Cultura y Deportes. Santa Cruz de Tenerife. (Spain).

Nowak H. 1994. "Die Tejeleita-Felsinschrift von El Hierro" Almogaren, XXIV-XXV, Hallein, Salzburg (Austria).

Orduña-Aznar E. 2005. Sobre algunos posibles numerales en textos ibéricos. Paleohispnaica IX. Paleohispanica. 5: 491-506.

Orduña-Aznar E. 2013. Los Numerales Ibéricos y el Vascoiberismo. Acta Paleohispánica XI. Paleohispanica. 13: 517-529.

PAIS F.J. 2008. Estrategias sociales en la explotación del territorio entre los Benehoaritas. E, XII Jornadas de Estudios de Lanzarote y Fuerteventura.

Pichler W. 1995. Neue Ostinsel-Inschriften (latino-kanarischeInschriften) auf Fuerteventura. Almogaren 26: 21-46. 
Pichler W. 2003. Las inscripciones rupestres de Fuerteventura. Ed. Calildo de Fuertevfentura, Puerta de Rosario, Fuerteventura, Canary Islands (Spain).

Poulianos A.N. 1969. Antropological data of the origin of the Creta: Proceedings 2nd International Cretan Studies. Athens (Greece).

Ruhlen M. 1994. The Origin of Language. Ed. John Wiley and Sons, inc. New York (USA).

Sota M., Lafitte P., Akesolo L. 1976. Diccionario Retana de Autoridades del Euskera. Ed. La Gran Enciclopedia Vasca. Bilbao (Spain).

Springer-Bunk R.A. 2001. La escritura Libico-Bereber en Canarias. Ed. CEPSA. (Gran Canaria, Spain).

Ulbricht M..J. 1990. Die Feldsildforschung auf Lanzarote. Almogaren XXI/2/1990, Hallein.

Ulbricht M..J. 2016. Canarian "pyramids" revisited - are they pre-Hispanic or recent?.Almogaren 46-47: 139-146.

Venemann T. 2003. Europa Vasconica. Ed. Monton-de-Gruyter. Berlin (Germany)

To cite this article:

Arnaiz-Villena A., Lopez-Nares A., Juárez I., Ruiz-del-Valle V., Callado A., H-Sevilla A., GomezCasado E. 2019. "Latín" rock scripts in Canary Islands are ancient Iberian inscriptions (Iberian-Guanche): A story of forgotten genetics, scripts, pyramids and other prehistoric artifacts.

International Journal of Modern Anthropology. 2 (12): 189 - 212

DOI: http://dx.doi.org/10.4314/ijma.v2i12.9

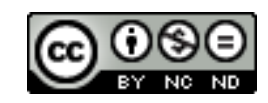

This article, as all articles published in this journal, is under The Creative Commons Attribution:

Attribution-NonCommercial-NoDerivatives 4.0 International (CC BY-NC-ND 4.0).

https://creativecommons.org/licenses/by-nc-nd/4.0/ 